geology, describing the Silurian rocks of the Mendips and the Carboniferous Limestone of many areas. The stimulating association with Vaughan led to great activity in this field, and Reynolds and his co-workers continued for many years to make known the structure of parts of Somerset and Gloucestershire. His views on the Lower Carboniferous were summarized in his presidential address to Section C of the British Association in 1926.

Throughout these years his department produced a flow of men varying in special interests, but all characterized by that width of view which was so typical of their professor. An energetic traveller and an indefatigable collector, he brought together material for an admirable museum. Nor were his energies confined to the work of the University, for he did much to foster the band of amateur geologists for which the Bristol district had long been known, and the geological section of the Bristol Naturalists' Society owes much to his devotion. An excursion handbook to the Bristol district, first published in 1912, contributed to local activities, and also helped to make the area one of the most widely known for student parties.

Prof. Reynolds served for a time on the Council of the Geological Society, from which he received the Lyell Medal in 1928. Among his many services to geology mention must be made of his work as secretary of the British Association Committee on Geological Photographs, which has done so much for the illustration of geological phenomena. The efforts which he made to replace material destroyed by enemy action in order to hand over the collections in good condition will not be forgotten by his colleagues. Always modest and unassuming, charitable in his judgments and warm in his appreciation, Reynolds made many friends and lost none. He will be remembered with gratitude and affection by many besides his own students. He leaves a widow and a daughter.

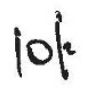

A. E. Trueman

\section{Prof. Edward L. Thorndike}

EDWARD LEe ThORNDIKE was born on August 31, 1874, and died a few days before his seventy-fifth birthday. In conformity with family tradition, he took his first 9 fee ats wesleyan University and then went to Hy vald, mere he worked with William James on the he hods by which animals learn, a subjectrick wis to be his life task, though in later decades $0 t$ wos the animal 'man' which chiefty infersted him, individually and in communities. Then at Columbia University he took the Ph.D. in 1898 with a dissertation which made psychological history, and in the same year James Russell initiated Thorndike's lifelong connexion with Teachers College, Columbia, by inviting him to an instructorship.

Largely on those early experiments were based Thorndike's three laws of learning, of which that called the Law of Effect has evoked most controversy. It is that learning is due to the glow of satisfaction which accompanies success. At first he emphasized equally the importance of the dissatisfaction which follows failure; but in his experiments on humans he considered that he had definitely proved that reward is more effective than punishment, a principle naturally of great importance in school, especially when combined with his stress on the desirability of the satisfaction coming as soon as possible after the success (not to be told until a week later which of one's golf strokes had been good would seriously delay learning !). He thought effect more important than frequency, and pointed out that in the early stages of learning to ride a bicycle we practice falling off much oftener than staying on. His psychology of learning has been attacked as mechanistic, and as not explaining sudden insight into a problem; and it is perhaps a little crude. But it works.

In 1904 his "Introduction to the Theory of Mental and Social Measurements" appeared, in the same year as Spearman's paper on the "Theory of Two Factors". Thorndike took up arms against Spearman's view, and though they approached one another somewhat in later years, they can never be said to have agreed. Thorndike's "Quantity Hypothesis", expounded in "The Measurement of Intelligence" (1926), perhaps indicates the nearest approach. In that same book appeared Thorndike's famous "C.A.V.D." tests of intelligence and his attempt at an absolute scale of intellect.

In later years Thorndike turned to the study of communities, his chief publication here being "Human Nature and the Social Order" (see Nature, Sept. 27, 1941). Like all his books and papers, this is too meaty to be light reading. But every here and there a striking phrase flashes out.

Thorndike received many honorary degrees, was a member of the U.S. National Academy of Sciences, and president in 1934 of the American Association for the Advancement of Science.

Early in his career he bought a wide tract of land up the Hudson, in what was then primeval woodland, built himself a house, and encouraged colleagues to settle around him, until there was quite a colony, to whom he was the tribal chieftain. He adored his wife, who survives him, as also do his daughter and three sons, all scientific workers, Robert Ladd being the psychologist among them. "Eddie" Thorndike had a great heart, as well as a great mind, and I wish that I had more space, and a readier pen, to tell of his wisdom and goodness.

Godfrey Thomson

\section{Mr. H. O. Newboult}

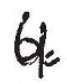

Harold NewBourt who died on August 11 at the age of fifty-two after ( short illness, was educated at Kingswood Schd pl find served in the First World War as an artillery facer on the Italian front. He took up his mathenatidal scholarship at Balliol College, Oxford, aft the War ; his undergraduate career, which inclucled the sharing of the junior mathematical schola ship with E. C. Titchmarsh, was all that was A teted of an able and gifted mathematician. Immediately after taking finals he succeeded his tutor, J. W. Russell, as lecturer at St. John's, and in 1925 was appointed fellow and tutor at Merton.

For some twenty-five years Newboult taught the mathematicians at Merton and St. John's, acquiring a high reputation as a tutor. Throughout this time he gave lectures, which were not only exceedingly popular with undergraduates, but which became an important and essential part of the Oxford mathematical school. He also undertook much examining and an increasing burden of administrative work in his College and the University. He acted as bursar of Merton in the war years and was proctor during 1944-45. He had wide interests in both the academic and athletic sides of University and College, and was for a long time treasurer of the Greyhounds R.F.C. In 1946 he published his book on "Analytical Method 
in Dynamics", and with T. W. Chaundy was writing a book on analytical geometry.

Newboult was an excellent tutor and lecturer in the whole range of the mathematical school ; but his particular contribution to mathematics lay in his wide knowledge of geometry, always available to colleagues and undergraduates alike. For many years and in various branches of the subject his lectures and teaching stimulated young men who have since established their own reputations in this field. No mere recital of his successes as a teacher and administrator can do him full justice. His influence was wide, for he brought to all his work the attitude of a scholar, remarkable acuteness and consistent fairness of mind.

J. H. C. Thоmpson

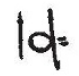

\section{Dr. G. S. Baker, O.B.E.}

Dr. George Stephen Baker, who died on August 16, had a world-wite reputation as a man of science and naval architect, who successfully applied the science of hyd dynamics to the design of merchant ships. Pr. Baker was born in 1877 and received his earp traning (1892-96) at the Royal Dockyard, Port nouth, as a shipwright apprentice. For his markd ability he was selected by the Admiralty in 1896 to continue his studies at the R.N.E. College, Keyham, for a year, followed by three years at the R.N. College, Greenwich, where he graduated in 1900 with a first-class professional certificate. He joined the Royal Corps of Naval Constructors, and, after working at Whitehall, he spent five years as Mr. R. E. Froude's assistant at the Admiralty Experiment Works at Haslar, carrying out ship model experiment work. He was then appointed professional secretary to Sir Philip Watts, director of naval construction. In 1910 he was selected by the Royal Society to become the superintendent of its new hydrodynamics laboratory at the National Physical Laboratory, a post which he occupied for thirty-two years. On his retirement at the age of sixty-five in
1942, he remained on the stafi until the end of the War, engaged on special research work. From 1945 until his death, he carried out work for the B.S.R.A.

While at Teddington, Dr. Baker read forty-three papers of high scientific merit before various technical societies and was awarded gold medals by three of them for outstanding research. $\mathrm{He}$ was a vicepresident of the Institution of Naval Architects. $\mathrm{He}$ became a doctor of science of the University of Durham in 1935. For his extremely able and timely work for the fighting services during 1914-18 he twice received the thanks of the Admiralty and was awarded the O.B.E.

Dr. Baker's fundamental researches in skin friction and propeller design greatly advanced the science of ship design, and his researches into the effect of changes in the form and dimensions of ships upon their resistance have become classics in ship designing circles. So successful were these researches that a direct result has been the saving of several million tons of fuel annually in the propulsion of ships.

Dr. Baker combined great technical ability with a driving force which enabled him to overcome all obstacles in the way of success. $\mathrm{He}$ possessed a singularly clear-thinking mind, and, by his accurate foresight of the future needs of shipowners, he was able to plan his researches so that he was almost always ready with new data before they were required. $\mathrm{He}$ became an authority on all matters where science touched ship design, and he served as an expert witness on cases of dispute and on many committees dealing with the resistance and propulsion of ships. Dr. Baker always commanded the respect and confidence of those with whom he worked, and his opinions were eagerly sought by those in difficulty. His close application to research work throughout his life left little time for hobbies, but he delighted to browse over early editions in libraries and bookshops, to garden and, when possible, to indulge in his love of sailing.

$\mathrm{He}$ is survived by his widow, three sons and a daughter.

\section{引) \\ Geography at the London School of Economics: Prof. R. O. Buchanan}

Dr. R. OgILvIE BUCHANAN who has been appointed to the chair of graphy the London School of Economics and Plitical iciehce, took his first degree in the Uni.e. ily of D,ago. After serving with the New Zeal ' forceoduring the First World War, he retfund to Great Britain and studied at the London Sched of Echr - mics. He has since served on the staff of the Department of Geography at University College, London, and he was elected to a readership in 1936. He has worked within the field of economic geography, publishing papers on the hydro-electric power and the agriculture of his native land, and his important monograph on the "Pastoral Industries of New Zealand", published by the Institute of British Geographers, is an admirable example of geographical method informed by economic insight. He has since made contributions to the study of plantation agriculture and world wheat supplies and is the author of a book on the "Economic Geography of the British Empire". He served with distinction as a senior maps officer with the Royal Air Force during

\section{nd VIEWS}

the recent War. The post to which he has now been elected is well adapted to give opportunity for the development of economic geography as a sound discipline deriving not from geography alone but also from economics and the kindred social sciences. The School of Geography to which he goes, and which is conducted jointly with King's College, is one of the largest in Great Britain and has heavy teaching and research commitments to the Faculties of Arts, Science and Economics. Prof. Buchanan's experience and interests will greatly strengthen the work in the Faculty of Economies.

\section{Botany at Delhi : Prof. P. Maheshwari}

Prof. P. MaHesuwari has recently been appointed professor of boany in the University of Delhi. He was born November 9, 1904, at Jaipur in Rajputana He took the B.Sc. and M.Sc. degrees in the Hniversity of Allahabad, and during 1927-30 he worked as research scholar at that University, being awarded the D.Sc. degree in 1931. He began his teaching career as lecturer in botany in Agra College (1930-37) and the University of Allahabad (1937-39). In 1939 he was appointed reader in botany and 